HOW

Volume 28, Number 2, pages 79 - 96

https://doi.org/10.19183/how.28.2.621

重OW

\title{
Dyslexic Individuals' Narratives on their Process of Becoming English Language Teachers
}

\author{
Narrativas de personas disléxicas sobre su proceso de convertirse \\ en profesores de inglés
}

\author{
Karen Andrea Cuervo-Rodríguez ${ }^{1}$ \\ Jairo Enrique Castañeda-Trujillo ${ }^{2}$
}

\begin{abstract}
This paper reports the findings of a narrative study with two pre-service English language teachers (PELTs) who have dyslexia. The main objective of the study was to understand how this condition of having dyslexia was present in becoming an English language teacher. The two PELTs participated in a life history interview as part of the data collection. By considering the main objective of the study, the researchers used the information collected to write the narratives and subsequently proceeded to interpret and analyze them. The findings show that dyslexia is as serious as any other disability, and it does generate rejection and lack of understanding on the part of teachers and other PELTs. Furthermore, negative feelings linked to the learning or teaching process are generated in PELTs with dyslexia, which leads them to hide their condition to avoid discrimination most of the time. However, findings also show that once negative feelings were overcome, PELTs turn their problem into an advantage, discovering themselves as more empathetic to those with special needs and making them
\end{abstract}

She is a last semester student in the B in Education with a major in English Language Teaching from Universidad Distrital Francisco José de Caldas, Bogotá, Colombia. She belongs to the research study group "Enseñanza y Aprendizaje en Lenguas Extranjeras, Cultura y Justicia Social" from Universidad Distrital. kacuervor@correo.udistrital.edu.co

ORCID ID: https://orcid.org/0000-0002-0888-9524

2 He is a $\mathrm{PhD}$ candidate in the Education Program at Universidad Distrital Francisco José de Caldas, Bogotá, Colombia. He is an Assistant Professor and researcher at Universidad Surcolombiana, Neiva, Colombia. He belongs to the research groups ILESEARCH and ESTUPOLI. His research interest centers on pre-service teachers' identities and professional development by using narratives.

jairo.castaneda@usco.edu.co

ORCID ID: https://orcid.org/0000-0002-3002-7947

Received: October 3rd, 2020. Accepted: March 1st, 2021.

This article is licensed under a Creative Commons Attribution-Non-Commercial-No-Derivatives 4.0 International License. License Deed can be consulted at https://creativecommons.org/licenses/by-nc-nd/4.0 
Karen Andrea Cuervo-Rodríguez,

Jairo Enrique Castañeda-Trujillo

more resourceful teachers. We conclude that although PELTs can turn their weaknesses into strengths, the role of teacher educators is also fundamental in the processes of identity construction; teacher educators might provide spaces and strategies to minimize the conditions that affect the performance of PELTs, both as language students and as language teachers.

Keywords: dyslexia, language teacher education, narrative inquiry, teacher identity

\section{Resumen}

Este artículo informa sobre los hallazgos de un estudio narrativo con dos profesores de inglés en formación (PELT) que tienen dislexia. El objetivo principal del estudio fue comprender cómo esta condición de tener dislexia estaba presente al convertirse en un profesor de inglés. Los dos PELTs participaron en una entrevista de historia de vida para recopilar datos para el estudio. Los investigadores utilizaron la información recopilada para redactar las narrativas y posteriormente procedieron a interpretarlas y analizarlas teniendo en cuenta el objetivo principal. Los resultados muestran que la dislexia es tan seria como cualquier otra discapacidad y genera rechazo y falta de comprensión por parte de los profesores y otros PELT. Además, en los PELT con dislexia se generan sentimientos negativos vinculados al proceso de aprendizaje o enseñanza, lo que los lleva a ocultar su condición para evitar la discriminación la mayor parte del tiempo. Sin embargo, los hallazgos también muestran que una vez que se superan los sentimientos negativos, los PELTs convierten su problema en una ventaja, ayudándolos a ser más empáticos con aquellos con necesidades especiales y haciéndolos maestros más ingeniosos. Concluimos que si bien los PELTs pueden convertir sus debilidades en fortalezas; el rol de los formadores de docentes también es fundamental en los procesos de construcción de identidad; los formadores de docentes pueden brindar espacios y estrategias para minimizar las condiciones que afectan el desempeño de los PELTs, tanto como estudiantes de idiomas como profesores de idiomas.

Palabras clave: dislexia, formación de profesores de idiomas, indagación narrativa, identidad del profesor

\section{Introduction}

This study arises as part of a hotbed of research in which the research interests revolve around pre-service English Language teachers (PELTs) as principal participants. Furthermore, the decision to focus on PELTs with special needs arises from one of the researchers due to an academic experience in which she analyzed different aspects of this population. Having this in mind, the researchers explored the possible special needs PELTs have, finding that some of the most indistinguishable were those that come because of having dyslexia. There is not much in the literature of the field about PELTs with dyslexia. Most of the studies focus on dyslexia in children, but not much in adolescents and adults, and less on people who are studying for bachelor's degrees in language education.

Moore et al. (2020) and Thorpe and Burns (2016) state that more exploration and research on diversity among teachers and their teaching practices are paramount. Hiscock and Leigh (2020, p. 7) mention that, concerning dyslexia, studies often focus on what 
happens to students, but what is related to teachers is invisible. In this sense, Riddick (2003) affirms that the invisibility and peculiarities of some teachers' special needs impact the construction of their professional identity. Furthermore, Thorpe and Burns (2016) state that "dyslexia contributed to the teacher's sense of identity and professional identity" (p. 204). This fact is due to the complexities and constant fluctuations of the teacher's identity that are negotiated through individual processes (which may be connected to personal interests, psychological or physical conditions) and those that are part of the environment and organizations.

The above leads us to think that if this high interest in special needs occurs in inservice teachers, the same may happen with PELTs who have just entered the educational system as teachers. Some Colombian scholars and researchers have become interested in understanding the PELTs' experiences from a narrative perspective (Castañeda-Trujillo \& Aguirre-Hernandez, 2018; Montoya-López, Mosquera-Andrade, \& Peláez-Henao, 2020; Torres-Cepeda \& Ramos-Holguín, 2019; Ubaque-Casallas \& Aguirre-Garzón, 2020). These studies show that becoming an English language teacher involves many processes and experiences that include learning, challenges, and decisions. However, none of them have focused their attention on those PELTs who have special needs related to their education e.g., in the particular case of this article, those who have dyslexia.

This article aims to understand two PELTs' experiences with dyslexia within an EFL undergraduate program. In this endeavor, the researchers began searching for PELTs who suffered from dyslexia and were willing to participate in this study. Yet, there were four possible participants at the beginning of the study. Only two of them committed to sharing what they had lived during their process of becoming English language teachers in the EFL undergraduate program.

As far as this study is concerned, PELTs are storytellers and their experiences emerge via stories that reflect the reality in a social space (Golombek \& Johnson, 2017; Sikes \& Gale, 2006, as cited in Mendieta, 2013, p. 136). Those stories or narratives allow the two PELTs with dyslexia to make the construction of their teacher identity visible and represent an opportunity to open spaces for further discussions on social justice issues within EFL undergraduate programs related to those other PELTs who have special needs.

\section{Theoretical Background}

As the main objective of this study is to understand the experiences of two PELTs with dyslexia. The theoretical constructs of dyslexia, teacher professional identity, and narrative inquiry are explained below. 
Karen Andrea Cuervo-Rodríguez,

Jairo Enrique Castañeda-Trujillo

\section{Dyslexia}

Dyslexia is considered a learning difficulty and, in some other views, a disability that is related to orthography, spelling, word order, and writing and reading in general. Martínez (2016) defines dyslexia as one of the specific learning disabilities considered as neurodevelopmental disorders with a biological origin as the basis for the cognitive abnormalities associated with the disorder's behavioral signs. Dyslexia, in the words of Alexander-Passe (2016), is a specific type of reading and writing difficulty based on the phonological processing of words. Additionally, Martínez (2016) defines dyslexia as follows:

Dyslexia is a specific learning disability that is neurobiological in origin. It is characterized by difficulties with accurate and/or fluent word recognition and poor spelling and decoding abilities. These difficulties typically result from a deficit in the phonological component of language that is often unexpected concerning other cognitive abilities and the provision of effective classroom instruction. Secondary consequences may include reading comprehension problems and reduced reading experience that can impede the growth of vocabulary and background knowledge. (p. 2)

The author affirms that the scientific community and the International Dyslexia Association (IDA) widely used the previous definition. This definition characterizes and states the repercussions of dyslexia in general terms, which is vital for this research study.

There are other difficulties in identifying the condition because there is a wide variety of characteristics (depending on the type of dyslexia) that are indicators of different conditions such as TDH, or as the difficulty of maintaining concentration. Notwithstanding, it is challenging to identify, especially in adults and adolescents; hence, dyslexia is more common than believed. Martínez (2016) states that many education and psychology professionals have studied this condition in-depth, trying to understand its origins, causes, and treatment. According to Dyslexia and Literacy International, at least $10 \%$ of the world population has dyslexia, which equates to around 700 million people (Galluzo, 2019).

Moreover, $52 \%$ of them claimed to have experienced discrimination during interview or selection processes. In Colombia, there is no information about adult cases. Still, in the children's cases, García (2016) states that, indicating the situation with adults, prevalence figures between 3.3\% and 5.5\% have been reported for this specific reading disorder in

82 Colombia. Additionally, she points out that the National Survey of Mental Health of Colombia does not provide data on the prevalence of learning disorders in childhood or those that persist into adulthood.

Sieroff (2017) mentions there are two types of dyslexia, acquired and developmental. Acquired dyslexia is a reading disorder frequently occurring after left or right posterior brain lesions. Developmental dyslexia is the most common type, but it does not happen because of a lesion; there is a broad classification depending on the characteristics: peripheral dyslexia 
involves reading impairments that result from deficits in the orthographic-visual analysis stage, and central dyslexia, which involves reading impairments in the later stages of the lexical and sub-lexical routes (Friedmann \& Coltheart, 2016).

There is not much research on dyslexia in adults. According to Martínez (2016), the research on cognitive aspects is the main current interest of the science of dyslexia in adults; however, there are almost no characterization works. They also mention that the number of adults that get a diagnosis is lower than the real number. Nevertheless, Pallaoro Moojen et al. (2020) said that there is currently a broad consensus in the literature regarding the persistence of deficits in phonological awareness, low word reading accuracy, and lack of reading fluency in adult individuals with dyslexia. Besides, Terras (2016) points out that "dyslexia impacts negatively upon self-esteem, socio-emotional well-being, relationships, education, and career choice" (p. 1). However, Soriano-Ferrer and Piedra Martínez (2017) highlight that those reading difficulties transcend the academic/cognitive domain, negatively affecting the affective-motivational plane. They said that internalizing problems, such as anxiety and depressive symptoms, are a constant among people with dyslexia in adulthood.

Since dyslexia is a complex condition with many characteristics and of various types, it is difficult to identify a person with this condition at first glance. Consequently, the condition becomes invisible and is not considered in the teaching and learning processes. Furthermore, dyslexia affects not only cognitive factors but also feelings and the emotional dimension, which negatively concerns the individual's identity, especially in terms of social relationships, career choice, and self-image as a professional. This invisibility means that individuals with dyslexia are not given the attention they deserve to overcome the learning problems they sometimes face more easily.

\section{Teacher Professional Identity}

This article addresses identity from the post-structural theory. Therefore, identity is dynamic, fluid, contradictory, and strongly connected with the context. This connection with the context and the various realities of the individual are built from the discourses since through them, the ways of being, thinking, and acting are expressed (Norton, 2013; Rudolph, Yazan \& Rudolph, 2018; Yazan, 2019). At this moment, we affirm that identity is diverse, therefore we speak of identities in the plural. According to Yazan (2019), PELTs develop identity categories like "age, gender, race, previous education, previous learning experiences, academic background, and individual characteristics" (p. 3) when they enter the EFL undergraduate program. These categories have a strong influence on what their identity will be as teachers (Selvi \& Rudolph, 2017).

This discursive process by which the PELTs evidence the construction of their identity is nourished from the interaction and participation in specific communities of practice (Yazan, 
2019). As they build these speeches, the PELTs show how their personal life stories, their commitment to teaching, their agency, and their emotions intersect with the other aspects of their identity (agency, investment, positioning). In this way, the construction of their narratives, which are a discursive form of their experiences, allows the PELTs to construct and reconstruct their identity (Barkhuizen, 2016; Bolivar, 2018; Sarasá, 2017). The construction of identity does not happen spontaneously or automatically but over time; it involves complex interactions that are combined in an individual and social or collective dimension. The individual dimension refers to personal experiences that build identity and is related to personal aspects in human development, such as motivation, self-esteem, image, etc. The social dimension occurs in socio-cultural interaction in many educational, institutional, and work contexts, while the collective refers to how individuals build themselves from others (Cervantes \& Dengo Vargas, 2019).

\section{Narrative Inquiry}

Understanding that identity is constituted or constructed through discourse and language and that it is the interaction among subjects that gives rise to these discourses, we can agree that identity acquires meaning from life stories (Norton, 2013; Varguese et al., 2005). These life stories are expressed through written or oral narratives. In themselves, these narratives describe the meaning of the events that individuals have experienced or those that they imagine for the future (Barkhuizen, 2016). Referring specifically to PELTs, Golombek and Johnson (2017) state that it is possible to externalize the understanding of PELTs from their past, present, and future experiences through narrative research.

Narrative inquiry becomes an alternative that PELTs have to make sense of their practice through their own language and life stories (Barhuizen, 2016; Barhuizen et al., 2013; Golombek \& Johnson, 2017). By doing this, PELTs enable their voices to be heard. These voices, reflected in the narratives, constitute sources of knowledge that affects the pursuit of adjustments, alternatives, and opportunities for the coming PELTs.

Similarly, narrative inquiry enables PELTs to become aware of their thoughts, feelings, and experiences. This awareness influences their decisions on a personal and professional level; this means that PELTs construct, reconstruct, and co-construct their identity as English teachers with this awareness and their decisions (Barkhuizen, 2013; Golombek \& Johnson, 2017). The previous statement shows the relevance of narrative research in developing the professional identity of PELTs and in-service teachers. According to Golombek and Johnson (2017), opening spaces for narratives within ELT programs is necessary. Within these spaces, the PELTs may make their intentions, motives, goals, and experiences explicit; thus, they can co-construct and give meaning to their beings as English language teachers together with others who have experienced both similar and different situations. 


\section{Research Methodology}

This study followed a qualitative narrative research stance. According to Merriam and Tisdell (2016), qualitative research aims to understand how people use language to construct their reality and interpret it by giving meaning to their experiences and theories. The reconstruction of these experiences occurs through texts, which are part of the social construction of realities, everyday practices, and everyday knowledge (Flick, 2009). One of the ways to understand these experiences is through narrative research.

In this study, narrative research allowed access to the participants' stories within a specific time, place, and events related to their experiences of being PELTs as well as being dyslexic (Polkinghorne, 1995). This constant reconstruction of memories allowed the participants to reconstruct their identities by their identifying themselves with other society members and showing affiliation with a particular group (Riessman, 2008). Furthermore, narratives provide access to long-term experiences through hindsight and imagination in multiple settings and contexts (Barkhuizen, Benson, \& Chik, 2013, p. 12). Narratives also allowed the two narrator-participants and the researchers to understand their background, as well as present and future implications of being dyslexic English language teachers. The narrative research involves them (narrator-participant and researchers) in creating the narrative and their interpretation (Barkhuizen, 2016).

To detail the narrator-participants' experiences, we used life story interviews. Atkinson (2007) defines life story interviews as a "subjective approach to expressing the part of one's life as a whole and conveying the meaning taken from them" (p. 233). Additionally, life story interviews reveal how a life event is constructed or reconstructed as a story, focusing on the narrator's whole life or upon one specific moment of their life. For this study, life story interviews were directed to understand the construction of teacher identity of two PELTs with dyslexia. As such, we follow the steps suggested by Atkinson (2007) to do a life story interview.

Firstly, the interview planning took place, assuming that the main concern was on becoming an English language teacher while having dyslexia. Secondly, doing the interview i.e., guiding the narrator through questions that were connected with the main issue of the study. Thirdly, the interview was transcribed, including only the words of the narratorparticipant telling the story. Finally, the stories were double-checked by the storyteller to be sure that they responded to what the narrator-participants wanted to tell (Birt et al., 2016).

\section{Context and Participants}

This study took place within the context of an EFL undergraduate program at a public university in Bogotá, Colombia. This program prepares PELTs to work in primary and 
secondary schools, and it lasts ten academic semesters. Throughout the major, PELTs take a series of courses and seminars that contribute to their professional development in terms of their level of command of the English language and their knowledge of didactics and other aspects of the pedagogical field (materials design, evaluation, ICT in education, research, etc.). Additionally, PELTs must complete four teaching practicum periods in a public school, two in primary school, and two in secondary school. Given the university's public nature, the students who enter it belong to different socioeconomic strata, significantly the lowest.

It is worth mentioning that finding PELTs willing to share their stories for this study was not easy due to the characteristics required of them: that they belong to the ELT undergraduate program, have dyslexia, and have finished at least one of the four teaching practicum courses. In the beginning, four PELTs fulfilled the necessary characteristics for this study. However, two of them did not accept participating, so we had only two participants in the end.

The two participants in this study were Esteban and Natalia (pseudonyms used for ethical reasons). Esteban was a 22-year-old PELT in the 8th semester, and Natalia was a 23-year-old PELT in the 9th semester. Both of them are middle-class. Even though Natalia's and Esteban's conditions are similar, they have some differences. Esteban's dyslexia was the result of a birth accident, and Natalia's is genetic. Esteban also has other conditions such as depression and TDH, but Natalia does not; she affirms that her nuclear family has this condition, so it is a part of their normality.

\section{Data Analysis}

As the research questions aimed to understand the experiences of two PELTs with dyslexia, the construction of the narratives began with life story interviews of them. Given that the teachers' identity does not depend solely on the experiences during their passage through the EFL undergraduate program, some of the interview questions aimed to understand PELTs' experiences while learning English and others related to everyday learning processes. Consequently, what the two PELTs answered in the interviews was used as data to write a story that included the most relevant information that allowed the understanding of the main research topic (Barkhuizen, Benson, \& Chik, 2013).

\section{Findings}

\section{Esteban's Experience}

Esteban's story began in 1997. He was born in Bogotá, at one of the hospitals dedicated exclusively to this type of procedure. Unfortunately, the night Esteban was born, conditions 
were not the best. The newborn needed to receive oxygen urgently, but the hospital had problems with electricity, and Esteban was not appropriately treated. Fortunately, the situation did not get worse, and Esteban's life was not in danger. However, few years later, the doctors noticed some problems with Esteban. He did not have adequate physical development, and he did not develop the ability to crawl when he was a baby. Esteban was sent to see some neurologists in the League against Epilepsy, who ruled out the doctors' initial mental retardation diagnosis. However, the neurologists found that Esteban had some learning problems, attention deficit, and coordination, among others.

For many years Esteban received help, but the situation did not change much, even during school. Esteban relates,

I had therapy and all these kinds of things, but it has been challenging. I don't have a good memory. I don't have good attention, which makes the classes a martyrdom for me. So it has not been easy because I try to pay attention. For example, I try to pay attention to what a person says, but I don't know.

However, when Esteban decided to enter the university, things got complicated. Esteban did not find the same support in the university that he used to have from teachers, psychologists, and coordinators at school; then, he was utterly alone. He explains it as follows,

Let's say that it has been a complicated process because I have had to fight alone, the teachers do not know it (about his dyslexic condition), and for me, it is problematic because I have to solve things myself.

Esteban explains that it is not easy for him to communicate with others about his condition, especially with teachers, and he clearly states that one of the reasons for this situation is social acceptance:

I think it's an internal struggle like you're trying to feel normal and admitting that someone is not comfortable in front of someone. You always try to fit in.

He adds,

Also, I think that at the university, the professors are very closed. They don't allow you to speak, to explain why I did things the way I did. Instead, they say something like 'ah! He didn't get it right, so his grade is 1' or 'ah! He didn't do it right, lousy job', there is no dialogue. [sic]

Esteban clearly understands that there are unfair situations within the university and that the lack of interest in the other does not allow us to understand that differences exist. He sees how conditions are the same and that there is no interest in the particularities of individuals or in their needs. 
For Esteban, the rejection was not something unknown. He had already experienced rejection; he recalls,

I think that, in a way, I feel a bit rejected, even sometimes by my colleagues. Sometimes they make fun of me. For example, when I have a presentation on a topic, some say 'oh, you said that word wrong' or 'ush, you're stuck presenting,' and they don't think that maybe I've been trying to learn what I needed to present for a week and what happens is that when the time comes to present it, I forget what I have to say.

These situations have created a barrier within Esteban, which does not allow him to be open to others and express what he truly thinks. He feels at a disadvantage and believes that he will never be able to be on the same level as his classmates or to comply satisfactorily with everything the teachers ask him to do.

In addition to his fear of telling teachers about his dyslexic condition, Esteban discovered that his classmates were people who had excelled in their schools, they had obtained good grades, and they were struggling to keep pace with their learning process during the major. He mentions,

At school, it wasn't obvious. Still, when I get to university, I find myself in a situation where I am at a disadvantage with others because others have good grades, good averages, and I don't. I see others picking up on things faster, and I don't.

To make matters worse, Esteban found that many of his classmates are competitive and want to stand out continually. In this way, each activity that was carried out in class became a competition to be the best, which overwhelmed Esteban. Despite his great efforts to keep up with others, Esteban reached a point of feeling exhausted. He says,

We all indeed have to make an effort, but I have been making a double effort in most activities. For example, teachers put a text to read, and for me, it is challenging because I am distracted. I cannot understand it at first, so what a person reads and understands in an hour takes me two.

Consequently, a feeling of inferiority grew in Esteban, to the point of feeling incapable of carrying out some of the requested activities. He expresses it as follows,

You have in your mind 'you have to be normal, you have to be normal' and suddenly admit that in front of a professor, it means that I do not have enough capacity or that I need a different process, and maybe I do. But let's say I'm afraid, not that he takes it the wrong way, but that he underestimates me and that kind of thing.

And again, the injustices within the program made Esteban feel that he was not the same as the others. This situation made him think that they minimized him by putting him aside and not appreciating or understanding his effort to learn a language and catch up on language teaching classes. 
Regarding learning a second language, Esteban saw that his process, in the case of English, has been difficult. And it is that Esteban is not only learning English as a foreign language but also Portuguese. However, it is not that the language was complicated; instead, he alludes to the English language teachers' methodologies and compares it with his Portuguese language teacher. Esteban says,

It has not been easy in the case of English, not because of the learning process but because of the teachers' methodologies. They are repetitive and very monotonous. Almost everyone follows the book and does not separate from it. On the other hand, the Portuguese teacher is more dynamic, and that has been very good.

As with the English language teachers, Esteban has not told the teacher anything about the reason for his dyslexia. Still, he feels that he is more valued, confident, and safer in learning this language, "I feel smart and happy because I think I can, while in English I cannot," he said.

However, not everything has gone wrong for Esteban. There are some advantages to being dyslexic, especially in the teaching process. He says, "I honestly think this has been good because it makes you more aware of the difference." Esteban has had the privilege of working in schools that follow inclusive education principles and also teach children with conditions such as blindness, autism, dyslexia, etc. This school experience has made him worried about his students facing the same situation as he. He says being there "has made him look for tools to teach them," focusing on each student's particular need. For example, Esteban says,

In my classroom, there was a deaf child, and the teacher of that course told me 'no, leave it there,' and I said 'but how can I leave it there,' so what I did was look for other alternatives, and it occurred to me that he could work with clay.

In this way, Esteban was able to empathize with the child and understand that his particular need is not a limitation for working in the English language class. Instead, he saw the opportunity to guide him and open the way to other teaching alternatives.

Ultimately, being a PELT with dyslexia has motivated Esteban to help others. He said, Living what

I have lived has allowed me to enjoy what I do and benefit children's lives even a little bit, so this has allowed me to take advantage of it to give something better to my students.

Esteban turned his dyslexic condition into a strength. However, it was not easy because he was often carried away by negative feelings and the affective impact of rejection. However, giving up and suffering were not options. He kept getting better and stronger. He said, 
Karen Andrea Cuervo-Rodríguez,

Jairo Enrique Castañeda-Trujillo

I do think it has an emotional effect, because for me, something that I do is not as good as what other people do, and that affects you a lot, but I think you should take that and make yourself stronger.

\section{Natalia's Experience}

Natalia has always wanted to be a teacher. From a very young age, her mother, an assiduous Christian, took her to the "Escuelita Dominical," initially to learn. Still, over time, it was Natalia who taught others. Since then, her goal was to become a teacher. Natalia felt that being a teacher was being herself, and she did not want to get away from what she longed for. So, when Natalia finished high school, she enrolled in the initial language teacher program at one of Bogota's public universities. Her dream was getting closer and closer to being fulfilled.

Natalia is dyslexic, a condition that she shares with other members of her family. When Natalia was still in school, she had some problems due to her condition. She remembers that staying in the schools where she studied was difficult for her. For example, when she was in eighth grade, she dropped out of school and did not return to school until she entered college; that is, she was educated at home. But this situation did not stop her desire to learn English and to learn how to teach it.

Natalia had some difficulties learning English as a foreign language. She remembers,

I don't have such marked dyslexia in written form in Spanish because since I was a child, I got used to reading a lot, and when I remember a word, I only remember when it is written. But, in English, I tend to get very confused with the grammatical structure or confuse the words. For example, when I want to say white, I say black, and I only realize it when others tell me about that. I have a terrible memory, and that I am not good at following directions.

Still, despite her difficulties, she never told her teachers that she was dyslexic. She did not feel that saying this was necessary; she thought she could handle it and that she could outdo herself,

I need the challenge to learn. I need to feel like I can do something to improve. But that is my case because each person is a different world.

Natalia really feels that her condition does not limit her and that it does not make her different from others. Nevertheless, Natalia had to face some specific situations daily in the classroom, and her teachers did not notice them,

I get bored when a teacher starts repeating things he has said because I got used to the fact that he had to pay more attention to detail, write, etc. I am having trouble with numbers because I have difficulty writing number sequences. I also confuse the right with the left, I have little perception 
of personal space, I am a bit clumsy, and I often confuse the opposites, which generates impressive bullying. But since I know how to handle it, eventually, this creates defense mechanisms to deal with everyone.

For Natalia, remaining silent and not telling anything about her condition was better. She was sure that she was not worth it, that neither the teachers nor her classmates could understand her and that she would be just wasting time. Eventually, she began trying to overcome her fear of teasing and her rejection. She has tried to create that self-image of an independent woman that has allowed her to move forward and not to give up in the process.

Natalia has already done some teaching practice and has been working in a cycle education institute ${ }^{3}$. During these experiences, she has encountered some obstacles as a teacher, which have made her think about her abilities to teach and about her own identity as a teacher. She mentions that she must make a double effort to verify mistakes in writing that is one of her weaknesses. She says,

For example, it affects when you have to be super vigilant with what you write on the board because there is nothing worse than a teacher who writes something wrong and leaves the error there and that students learn it with errors. You also need to be very careful in the structures you are talking about, and if you make a mistake, you should correct it in time.

Natalia implies that she must be different from other PELTs, especially during the teaching practicum. Her identity as a teacher is affected by her condition because she needs to be more careful since she does not want to be taken as an unknowledgeable teacher. In addition, the student's reaction is relevant, and how she deals with different situations is vital. She adds,

Students make fun of you when you make a mistake and more because in my speech, if you notice that I deviate a little and talk too much, but you say, 'Guys, that's learning. Because I am a teacher, it does not mean that I know everything perfectly'.

These experiences have helped Natalia see her dyslexic condition from a different perspective. She has even found some positive things about having this condition as she says,

I have never seen dyslexia as a learning disability but rather as a way of seeing and understanding the world. It becomes a strength. Although everyone overcomes their challenges in their own way, I feel that the good thing about this condition is that I become more understanding for people who do not see it that way and that there are many ways to be understood, so it makes me a little wittier.

Cycle education institutes are regulated by the Colombian Ministry of National Education, and allow adolescents, youth and adults to advance in their secondary studies in a more flexible way than a regular school, since it gives the option of taking two school grades in a year. 
Karen Andrea Cuervo-Rodríguez,

Jairo Enrique Castañeda-Trujillo

\section{Learnings from the Two PELT' Experiences}

From the narratives of dyslexic PELTs, we have found some commonalities and differences in identity construction. Likewise, we have been able to identify some coincidences with what was explained in some previous studies related to the condition and its impact on the professional development of teachers in training in terms of identity. Also, some ideas and thoughts of the PELTs coincide with those in previous studies related to the condition and its impact on pre-service teachers' professional development in terms of identity.

There are similarities between Esteban and Natalia. They have been facing many challenges during their lives. For instance, both of them experienced bullying. Esteban lived this experience when he mispronounced some words, and his peers laughed and judged him. The same happened to Natalia when she made spelling mistakes on the board. Esteban and Natalia also experienced rejection from their peers, and they usually were called lazy, slow, and awkward. Esteban and Natalia have experienced discrimination; this has affected their teacher identity directly. Due to this rejection, they could probably hide their difficulties so as to become accepted. This mask that they put on may protect them from future professional issues with students and the educational staff. When dyslexia is seen as a problem or an illness, the most probable response is that teachers with this condition will be rejected because that could affect students' learning process and cause difficulties with their students' writing and spelling (Hiscock \& Leigh, 2020).

Another challenge is related to their learning processes. Esteban and Natalia expressed that they have had to face many difficulties in learning a second language. Both said that they had problems with pronunciation, spelling, and grammar. Pallaoro Moojen et al. (2020) noted that there is currently a broad consensus in the literature regarding the persistence of deficits in phonological awareness, low word reading accuracy, and lack of reading fluency in adults with dyslexia.

The professional development of pre-service teachers' identity is vital for teacher educators' role during the learning process. Their beliefs and actions shaped and reshaped their students' identity (Sardabi, Biria, \& Golestan, 2018, p. 618). Some teacher educators ignore their students, which results in an invisibilization of their difficulties and their selves. Esteban expressed that he differentiated two different teaching methods; he exemplifies it through his experiences learning Portuguese as a third language. His teacher was very openminded and assigned activities different from copying on the board and teaching grammar rules (which are not recommended for students with learning difficulties). Esteban expressed that it was a dynamic class, and thanks to his teacher, he felt comfortable. While his English language teachers were different, Esteban pointed out that the teachers are not interested in their students' differences; they are more preoccupied with scores and with working with the fastest and more productive learners in the class. 
Natalia and Esteban expressed that their English language teachers are not prepared to face the situations that they have had to face with them, such as a lack of attention and time management while solving the different classroom activities. Their teachers are not much involved or informed about their condition. Esteban and Natalia think that some factors contribute to this, such as lack of communication between teacher-student, fear of rejection, and perceptions of the teachers and partners about themselves. This last factor is vital to professional identity because identity is constructed through social interaction. If they are rejected or seem as "different" or "bad" by the others, it implies an emotional affectation, for example, loneliness and frustration (Bolívar, 2018).

However, they took this feeling and transformed it into an armor. Both agree this is a personal fight, and that they could not give up. Esteban and Natalia see their condition as a challenge, in fact, a challenge that becomes a strength. They took advantage of their condition in different ways while teaching. They have some things in favor of their teaching; first, they have to make an extra effort, which helps them obtain refined results; this makes them more conscientious about the difference in the classroom. They project themselves as better and more open-minded teachers than the ones that they have found during their degree studies. They expect to be able to see students' difficulties and understand their situations and contexts. Then, they will be able to bring a change to English language education in inclusive classrooms.

This point is vital for professional identity. Moore et al. (2020) mention that teachers with disabilities can have an advantage in relating to their students with disabilities. They pointed out that it "facilitates positive professional identity development and a sense of purpose for teacher candidates" (p. 4). They see themselves as resilient and excellent teachers because of the identity they have constructed. However, the fact that they have to face a complicated process of identity construction is evident. The previous is due to their perceptions of what makes a "good teacher," which has been constructed during their whole learning process; furthermore, as they were rejected by reason of being dyslexic, they might have assumed that they were insufficient to fill this concept of "good." In fact, their professional identity, which should be constructed under the guide of education, was built by themselves and their experiences, the ones that have empowered them to discover who they can be as teachers.

\section{Conclusions}

There are a number of critical points to conclude in this research study. One of the most important is the necessity of more research in this field of learning difficulties, with dyslexia and other conditions that could affect PELTs' professional identity. This lack of information invisibilizes the problem and the population itself, thus creating more barriers for the PELTs; this resorts to discrimination. 
Another important point is that PELTs have to face many challenges that affect their professional identities. Rejection, bullying, and academic problems make them feel inferior and lose their self-confidence, which affects their self-esteem, vital for professional identity construction.

The role of teacher educators is crucial for their students' professional identity development. They have to be open-minded, communicative, and understanding; they have to look for their students' needs and be attentive to those who may need more help. Teacher educators are the ones that contribute to future generations of teacher development. They have to teach theoretical knowledge, and the abilities required to face the unexpected, and this knowledge has to be coordinated with their actions. Maunsell (2020) highlights that "Foreign language learners with dyslexia should benefit from a positive and motivating learning environment" (p. 102). It means that teacher educators must motivate and provide a good learning environment, shaping their students' identity, besides teaching theoretical knowledge.

The last point to mention refers to the positive attitudes of being dyslexic; taking advantage of adverse situations is possible. Despite the challenges of PELTs in this condition, they have been able to reshape their self-image, transform their barriers into a strength, and focus on their role in their classrooms, especially with their students and their differences. It is evident that these PELTs with dyslexia see themselves as more suitable to teach those having the same condition because they can understand their needs and context by their own experiences.

\section{References}

Alexander-Passe, N. (2016). Dyslexia, success, and post-traumatic growth. Asia Pacific Journal of Developmental Differences, 3(1), 87-130. https://doi.org/10.3850/S2345734114000232

Atkinson, R. (2007). The life story interview as a bridge in narrative inquiry. In D. J. Clandinin (Ed.), Handbook of narrative inquiry: Mapping a methodology (pp. 224-245). Sage Publications, Inc.

Barkhuizen, G., Benson, P., \& Chik, A. (2013). Narrative inquiry in language teaching and learning research. Routledge.

Barkhuizen, G. (2016). Narrative approaches to exploring language, identity and power in language teacher education. RELC Journal, 47(1), 25-42. https://doi.org/10.1177/0033688216631222

Birt, L., Scott, S., Cavers, D., Campbell, C., \& Walter, F. (2016). Member checking: A tool to enhance trustworthiness or merely a nod to validation? Qualitative Health Research, 26(13), 1802-1811. https://doi.org/10.1177/1049732316654870

Bolívar, A. (2018). Una dirección necesitada de identidad profesional. Cuadernos de pedagogía, 490 (junio), 60-64.

Castañeda-Trujillo, J. E., \& Aguirre-Hernández, A. J. (2018). Pre-service English teachers' voices about the teaching practicum. HOW, 25(1), 156-173. https://doi.org/10.19183/how.25.1.420 
Cervantes, G. M., \& Dengo Vargas, M. C. (2019). Identidad profesional y formación docente universitaria: Un proceso en construcción desde la mirada del estudiantado. Actualidades Investigativas en Educación, 19(1), 196-215. http://dx.doi.org/10.15517/aie.v19i1.35379

Flick, U. (2009). An introduction to qualitative research (4th ed.). Sage.

Friedmann, N., \& Coltheart, M. (2016). Types of developmental dyslexia. In A. Bar-On \& D. Ravid (Eds.), Handbook of communication disorders: Theoretical, empirical, and applied linguistics perspectives (pp. 1-37). De Gruyter Mouton. https://doi.org/10.1515/9781614514909-036

Galluzo, M. (2019). We need to talk about dyslexia at work. Worklife, BBC.

García, N. B. (2016). Adultos con trastornos del aprendizaje: dificultades adaptativas. Poiésis, 121 131. https://doi.org/10.21501/16920945.2099.

Golombek, P. R., \& Johnson, K. E. (2017). Re-conceptualizing teachers' narratives inquiry as professional development. Profile: Issues in Teachers' Professional Development, 19(2), 15-28. https:// doi.org/10.15446/profile.v19n2.65692

Hiscock, J. R., \& Leigh, J. S. (2020). Exploring perceptions of and supporting dyslexia in teachers in higher education in STEM. Innovations in Education and Teaching International (RIIE). https:/ / doi.org/10.1080/14703297.2020.1764377

Martínez, E. D. (2016). Dislexia en adolescentes y jóvenes adultos: caracterización cognitiva y afectivo-motivacional. Universidad de Valencia.

Maunsell, M. (2020). Dyslexia in a global context: a cross-linguistic, cross-cultural perspective. Latin American Journal of Content \& Language Integrated Learning, 13(1), 92-113. https://doi. org/10.5294/laclil.2020.13.1.6

Mendieta, J. A. (2013). Narrative research: An alternative approach to study language teaching and learning. Folios, 37, 135-147. https://doi.org/10.17227/01234870.37folios135.147

Merriam, S. B., \& Tisdell, E. J. (2016). Qualitative research: A guide to design and implementation (4th ed.). Jossey-Bass.

Montoya-López, J. C., Mosquera-Andrade, A. V., \& Peláez-Henao, O. A. (2020). Inquiring preservice teachers' narratives on language policy and identity during their practicum. HOW, 27(2), 51-72. https://doi.org/10.19183/how.27.2.544

Moore, A., Kern, V., Carlson, A., Vaccaro, A., Kimball, E. W., Abbott, J. A., Troiano, P. F., Newman, B. M. (2020, April). Constructing a sense of purpose and a professional teaching identity: Experiences of teacher candidates with disabilities. The educational forum, 1-14. https:// doi.org/10.1080/00131725.2020.1738608

Norton, B. (2013). Identity and second language learning: Extending the conversation ( $\left.2^{\text {nd }} \mathrm{ed}.\right)$. Multilingual Matters.

Pallaorro Moojen, S. M., Alves Gonçalves, H., Bassôa, A., Navas, A. L., de Jou, G., \& Sánchez Miguel, E. (2020). Adults with dyslexia: How can they achieve academic success despite impairments in basic reading and writing abilities? The role of text structure sensitivity as a compensatory skill. Annals of Dyslexia, 115-140. https://doi.org/10.1007/s11881-020-00195-w 
Karen Andrea Cuervo-Rodríguez,

Jairo Enrique Castañeda-Trujillo

Polkinghorne, D. E. (1995) Narrative configuration in qualitative analysis. International Journal of Qualitative Studies in Education, 8(1), 5-23. https://doi.org/10.1080/0951839950080103

Riddick, B. (2003). Experiences of teachers and trainee teachers who are dyslexic. Int. J. Inclusive Education, 7(4), 389-402. https://doi.org/10.1080/1360311032000110945

Riessman, C. K. (2008). Narrative methods for the buman science. Sage.

Rudolph, N., Yazan, B., \& Rudolph, J. (2018). Negotiating 'ares,' 'cans,' and 'shoulds' of being and becoming in English language teaching: Two teacher accounts from one Japanese university. Asian Englishes, 21(1), 22-37. https://doi.org/10.1080/13488678.2018.1471639

Sarasá, M. (2017). Las posibilidades descolonizadoras de las narrativas en la formación inicial del profesorado. Revista de Educación, 12(12), 49-66.

Sardabi, N., Biria, R., \& Golestan, A. A. (2018). Reshaping teacher professional identity through critical pedagogy-informed teacher education. International Journal of Instruction, 11(3), 617634. https://doi.org/10.12973/iji.2018.11342a

Selvi, A. F., \& Rudolph, N. (2017). Teachers and the negotiation of identity: Implications and challenges for second language teacher education. In J. D. Martínez Agudo (Ed.). Native and non-native teachers in English language classrooms: Professional challenges and teacher education (pp. 258272). De Gruyter Mouton.

Sieroff, E. (2017). Acquired spatial dyslexia. Annals of physical and rehabilitation medicine, 60(3), $155-$ 159. https://doi.org/10.1016/j.rehab.2015.07.004

Soriano-Ferrer, M., \& Piedra Martínez, E. (2017). A review of the neurobiological basis of dyslexia in the adult population. Neurología (English ed.), 50-57. https://doi.org/10.1016/j. nrleng.2014.08.008

Torres-Cepeda, N. M., \& Ramos-Holguín, B. (2019). Becoming language teachers: Exploring student-teachers' identities construction through narratives. GIST - Education and Learning Research Journal, 18, 6-27. https://doi.org/10.26817/16925777.441

Terras, M. (2016). Dyslexia in adulthood: Challenges, barriers, and enablers. British Dyslexia Association 10th International Conference.

Thorpe, A., \& Burns, E. (2016). Managers' and teachers' perspectives of dyslexic teachers in the English and Finnish further education workforce: New insights from organizational routines. Oxford Review of Education, 42(2), 200-213. https://doi.org/10.1080/03054985.2016.1157062

Ubaque-Casallas, D., \& Aguirre-Garzón, E. (2020). Re-Signifying teacher epistemologies through lesson planning: A study on language student teachers. Profile: Issues in Teachers' Professional Development, 22(2), 131-144. https://doi.org/10.15446/profile.v22n2.80687

Varghese, M., Morgan, B., Johnston, B. \& Jonson, K. (2005). Theorizing language teacher identity: Three perspectives and beyond. Journal of Language, Identity, and Education, 4(1), 21-44. https:/ / doi.org/10.1207/s15327701jlie0401_2

Yazan, B. (2019). Identities and ideologies in a language teacher candidate's autoethnography: Making meaning of storied experience. TESOL Journal. 10: e500. https://doi.org/10.1002/ tesj. 500 